ORIGINAL ARTICLE

\title{
Analysis of properdin (BF) genotypes associated with litter size in a commercial pig cross population
}

\author{
B. Buske, C. Brunsch, K. Zeller, P. Reinecke \& G. Brockmann \\ Department of Breeding Biology and Molecular Genetics, Institute of Animal Sciences, Agricultural and Horticultural Faculty, Humboldt-University of \\ Berlin, Berlin, Germany
}

\author{
Correspondence \\ Bernd Buske, Department of Breeding Biology \\ and Molecular Genetics, Institute of Animal \\ Sciences, Agricultural and Horticultural \\ Faculty, Humboldt-University of Berlin, 10115 \\ Berlin, Invalidenstr. 42, Germany. \\ Tel: +49 0302093 6449; Fax: +490302093 \\ 6397; E-mail: bernd.buske@staff.hu-berlin.de \\ Received: 30 August 2004; \\ accepted: 28 February 2005
}

\begin{abstract}
Summary
Properdin $(B F)$ was investigated as a candidate gene influencing litter size in a commercial pig cross population. The $B F$ gene was chosen because of its integral role in influencing uterine epithelium growth and because several quantitative trait loci (QTL) with impact on reproductive traits have been detected near the centromere of porcine chromosome 7. A total of $123 \mathrm{~F}_{2}$ (Large White $\times$ Landrace) $\times$ Leicoma sows were genotyped using polymerase chain reaction-restriction fragment length polymorphism (PCR-RFLP) method. The sows were divided into two extreme performance groups, one with a high litter size $(\mathrm{n}=61, \geq 14.3$ piglets per litter) and the other with a low litter size $(\mathrm{n}=62, \leq 11.3$ piglets per litter). Although genotype and allele frequencies were uneven with $2.4 \%(A A), 16.3 \%(A B), 81.3 \%(B B)$ and $0.11(A): 0.89(B)$, the allele $A$ was the unfavourable one, leading to less offspring. With regard to the level of significance at $\mathrm{p}<0.05$, the total number of born (TNB) and number of born alive (NBA) piglets were associated with $B F$ genotypes. The genotype $A A$ led to 10.55 TNB and $10.00 \mathrm{NBA}$, whereas the genotype $B B$ led to 13.19 TNB and 12.11 NBA. The genotype $A B$ was intermediate. In future, a systematic mating test is necessary in order to obtain more balanced genotype frequencies. Furthermore, it should be taken into consideration that the investigated polymorphism is located in an intronic region and the causative mutation is not clear yet.
\end{abstract}

\section{Introduction}

The improvement of reproductive traits in livestock has been of increasing interest especially in swine, where moderate increases in litter size can lead to large profits (Vincent et al. 1998). However, selection programmes are almost based only on phenotypical traits which are laborious, expensive and especially, in pig production, time consuming. Marker-assisted selection (MAS), employed in conjunction with traditional selection methods, could accelerate the rate of change in economically important traits. In order to detect the loci for a special trait, two strategies are commonly employed: quantitative trait loci (QTL) analysis and the candidate gene approach (Rothschild et al. 2000). Several QTL regions for reproductive traits in swine have already been detected, among them QTL for uterine length, ovulation rate and litter size near the centromere of porcine chromosome 7. However, until now, no gene responsible for litter size has been identified on this chromosome. Furthermore, a putative murine QTL that influences heterosis in litter size was found on mouse chromosome 17 (Brunsch et al. 1998) which is homologous to the major histocompatibility complex (MHC) class III region on porcine chromosome 
7 (Peelman et al. 1996). One of the genes in the MHC class III region encodes properdin. The properdin $(B F)$ gene has been mapped near the centromere of porcine chromosome 7 at 7 cen (Pinton et al. 2000) and 7 1/2pl1-pl2 (Ponsuksili et al. 2001). Because properdin has a physiologically important function in reproductive traits such as uterine epithelium growth (Hasty et al. 1993) and in litter size in mice in conjunction with other genes (Matsumoto et al. 1997), properdin (BF) was selected as the candidate gene for litter size in swine. In most cases, reference families were used for applying either QTL analyses or candidate gene approaches. The aim of this study was to investigate, whether the $B F$ gene is associated with litter size in a commercial sow population and to compare the results with the published QTL found for reproductive traits on porcine chromosome 7 .

\section{Material and methods}

\section{Animals}

A commercial pig population was used from a German sow farm (Polkenberg, Sachsen, Germany). A total of 447 (Large White $\times$ Landrace) $\times$ Leicoma sows that had four litters at minimum represented the basic population. Two extreme performance groups were formed according to the total number of piglets born (Table 1): The high-performance group consisted of 61 sows with at least 14.3 piglets from the second up to the fourth litter, whereas the low-performance group consisted of 62 sows with less than 11.3 piglets from the second up to the fourth litter. The first litter was ignored, because, in general, first litters are more uneven than the following litters. All sows were artificially inseminated with Piétrain boar semen with a constant amount of fresh sperm. The feeding and housing regime of the sows were kept constant. Directly after farrowing, the total number of born (TNB) and the number of born alive (NBA) piglets were recorded. DNA was obtained from ear chondral tissue and was isolated using standard methods.

Table 1 Genotyped sows of two performance groups

\begin{tabular}{|c|c|c|c|c|c|}
\hline \multirow{3}{*}{$\begin{array}{l}\text { Performance } \\
\text { group }\end{array}$} & \multirow{3}{*}{$\begin{array}{l}\text { Number of } \\
\mathrm{F}_{2} \text { sows }\end{array}$} & \multicolumn{4}{|c|}{ Litter size (second to fourth litter) } \\
\hline & & \multicolumn{2}{|l|}{ TNB } & \multicolumn{2}{|l|}{ NBA } \\
\hline & & Mean & Range & Mean & Range \\
\hline High & 61 & 15.73 & $12-24$ & 14.10 & 9-19 \\
\hline Low & 62 & 10.39 & $3-14$ & 9.83 & $3-14$ \\
\hline
\end{tabular}

\section{Genotyping}

Polymerase chain reaction-restriction fragment length polymorphism (PCR-RFLP) for the properdin $(B F)$ gene (GenBank accession no. M59240) was performed according to the method developed by Jiang \& Gibson (1998) with modifications. Primer sequences were as follows: Forward: 5'-ACT GCT ATG ACG GTT ACA CTC TCC G-3'; reverse: 5'-TCC AAG AGC CAC CTT CCT GG-3'. PCR conditions were the following: Approximately $150 \mathrm{ng}$ of genomic DNA was amplified in a final volume of $25 \mu \mathrm{l}$ containing $0.4 \mu \mathrm{M}$ of each primer (BioTeZ, Berlin, Germany), $0.2 \mathrm{~mm}$ dNTPs, $3 \mathrm{~mm} \mathrm{MgCl}_{2}$, $1 \mathrm{x}$ Taq reaction buffer without $\mathrm{MgCl}_{2}$ and $1 \mathrm{U}$ Taq DNA polymerase (Invitek, Berlin, Germany). After denaturation at $94^{\circ} \mathrm{C}$ for $2 \mathrm{~min}, 30$ amplification cycles comprising denaturation at $94^{\circ} \mathrm{C}$ for $30 \mathrm{~s}$, annealing at $55^{\circ} \mathrm{C}$ for $30 \mathrm{~s}$, and extension at $72^{\circ} \mathrm{C}$ for $50 \mathrm{~s}$ were performed followed by a final 5 -min extension step at $72^{\circ} \mathrm{C}$. Subsequently, the PCR fragment was digested with the restriction enzyme SmaI (New England BioLabs, Frankfurt, Germany) to show the polymorphism. The amplified fragment was incubated in a total volume of $14.5 \mu \mathrm{l}$ containing $12 \mu \mathrm{l}$ of the PCR product, $5 \mathrm{U}$ of enzyme, $1.5 \mu \mathrm{l}$ restriction buffer at $25^{\circ} \mathrm{C}$ for $3 \mathrm{~h}$. Restriction fragments were examined by electrophoresis on $1.5 \%$ agarose gel with $1 x$ TBE buffer. The gels were stained with ethidium bromide and photographed. The PCR-RFLP assay yielded two bands of 237 and 153 bp (genotype $A A$ ), a single 390-bp band (genotype $B B$ ) and all three bands for the genotype $A B$ as it is described by Jiang $\&$ Gibson (1998).

\section{Statistical analyses}

The statistical analyses were performed with the SAS programme (version 8.2). First of all, it was investigated, if a special genotype occurs significantly in one of the two performance groups $(p<0.05)$. For this purpose, the chi-square test with the extension of the Fisher's exact test was used. The latter one was performed in order to determine the exact p-values for the frequencies of the genotyped sows. Furthermore, it was investigated by multivariate analysis of variance including the Duncan test, whether a special genotype has an influence on the traits TNB and NBA. The Duncan test was performed because this test can distinguish significant differences between mean values for the measured traits even if genotype frequencies are uneven. This test is less conservative than the others and is in that cases 
applicable, when the numbers within class variables are unequal. The following linear model was employed for the analysis of variance:

$$
Y_{i j k l}=\mu+\mathrm{gt}_{i}+\operatorname{lno}_{j}+\operatorname{pgr}_{k}+\operatorname{gt}(\operatorname{lno})_{i j}+\operatorname{gt}(\operatorname{pgr})_{i k}+e_{i j k l}
$$

with $Y_{i j k l}=$ observation value for TNB and NBA; $\mu=$ aggregate mean value; gt $_{i}=$ fixed effect of genotype $i ; \operatorname{lno}_{j}=$ fixed effect of litter number $j ; \operatorname{pgr}_{k}=$ fixed effect of performance group k; gt $(\operatorname{lno})_{i j}=$ fixed effect of genotype $i$ within litter number $j$; $\operatorname{gt}(\text { pgr })_{i k}=$ fixed effect of genotype $i$ within performance group $k$ and $e_{i j k l}=$ error.

Dominance effects $(d)$ were estimated as the deviation of the heterozygotes from the mean value of the homozygotes and additive effects $(a)$ as the mean value from both homozygotes. The degree of dominance $(D)$ was calculated with $D=d / a$.

\section{Results}

Genotype distribution, genotype and allele frequencies

Table 2 shows the distribution of the different genotypes for $B F$ within the two performance groups of commercial (Large White $\times$ Landrace) $\times$ Leicoma sows.

Among all genotyped sows, the genotype frequencies were $2.4 \%$ for $A A, 16.3 \%$ for $A B$ and $81.3 \%$ for $B B$. The allele frequencies were 0.11 and 0.89 for alleles $A$ and $B$, respectively. The genotype distribution between the high- and the low-performance group showed a p-value (0.055) slightly over the level of significance of $\alpha=0.05$.

Influence of the genotype on litter size (TNB and NBA)

Table 3 shows the influence of the genotype on litter size as well as additive and dominance effects for the traits TNB and NBA of the commercial (Large White $\times$ Landrace) $\times$ Leicoma sows.

Both, TNB and NBA were influenced significantly by the genotype. In comparison with the $A$ allele, the $B$ allele was the favourable one, leading to more

Table 2 Genotype distribution of the BF gene in the performance groups

\begin{tabular}{llll}
\hline & High-performance & Low-performance & \\
Genotype & group $(n=61)$ & group $(n=62)$ & Total $(n=123)$ \\
\hline$A A$ & 0 & 3 & 3 \\
$A B$ & 7 & 13 & 20 \\
$B B$ & 54 & 46 & 100 \\
\hline
\end{tabular}

Table 3 Influence of BF genotypes on litter size in commercial sows

\begin{tabular}{lccccc}
\hline Genotype & TNB & SD & NBA & SD & $\begin{array}{l}\text { Number of } \\
\text { litters }\end{array}$ \\
\hline$A A$ & $10.55^{\mathrm{a}}$ & 2.96 & $10.00^{\mathrm{a}}$ & 2.83 & 9 \\
$A B$ & $12.63^{\mathrm{b}}$ & 3.58 & $11.43^{\mathrm{b}}$ & 2.86 & 60 \\
$B B$ & $13.19^{\mathrm{b}}$ & 3.54 & $12.11^{\mathrm{b}}$ & 3.11 & 300 \\
$\mathrm{a}$ & 1.32 & & 1.06 & & \\
$d$ & 0.76 & & 0.38 & & \\
$D$ & 0.58 & & 0.36 & & \\
\hline
\end{tabular}

Mean values in the same column with different superscripts significantly differ at $p<0.05$.

$a=$ additive effect; $d=$ dominance effect; $D=$ degree of dominance.

offspring. However, it is also to indicate, that the least squares mean values including the performance group do not confirm this result. There were dominance effects of 0.76 and 0.38 and additive effects of 1.32 and 1.06 for TNB and NBA respectively. The degree of dominance was 0.58 and 0.36 , and hence, it follows that this can be considered according to the assumption of partial dominance $(0<D<1)$ for both TNB and NBA respectively.

\section{Discussion}

In Figure 1 we present a compilation of all known QTL regions on SSC7 with an influence on reproductive traits and the cytogenetic position of the gene properdin $(B F)$. $B F$ has been mapped on the $p$ arm near the centromere to SSC7 and overlaps well with QTL regions for reproductive traits such as litter

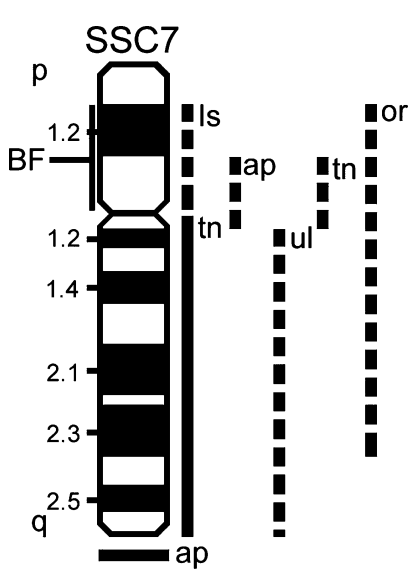

Figure 1 Cytogenetic map of porcine chromosome 7 showing known QTL affecting reproductive traits in sows. ap = age of puberty, Is = litter size, or $=$ ovulation rate, $\mathrm{tn}=$ teat number, $\mathrm{ul}=$ uterine length; bold solid lines $=$ genome wide level of significance $<0.05$, dashed lines $=$ genome wide level of significance $>0.05$; cytogenetic position of the bold line at the end of the chromosome (ap) was not evaluable; $\mathrm{BF}=$ properdin. 
size (de Koning et al. 2001), ovulation rate (Wilkie et al. 1999) and age of puberty (Cassady et al. 2001).

Almost all investigations with regard to QTL analyses and candidate gene approaches were performed with reference families. We used a commercial sow population, and therefore it was unlikely to obtain equal allele and genotype frequencies. However, as a result, it can be assumed that the $A$ allele is the unfavourable one, producing less piglets than the $B$ allele (Table 3). Furthermore, this allele occurred more in the low-performance group (Table 2); however, the level of significance was not reached. Therefore, it seems that the unfavourable $A$ allele has been reduced in this population over the years by phenotypical selection. A similar experimental setup with regard to effects of RYRI and ESR genotypes on the fertility of sows was performed by Matoušek et al. (2003). They investigated two elite herds of Large White sows and also observed unequal genotype and allele frequencies concerning the RYRl gene locus. Although the number of animals (124 sows) was rather low, the authors were able to find significant differences for the trait TNB, because they evaluated six litters for each sow. Although there are many QTL on SSC7 affecting reproductive traits, so far no gene on this chromosome has been identified that shows an effect on fecundity. Cassady et al. (2001) reported a significant QTL for age at puberty and a suggestive QTL for teat number on porcine chromosome 7. A significant QTL for teat number was also reported by Wada et al. (2000), but at another position. Teat number plays a significant role when there are more piglets than teats. Hence, the selection on litter size may require improvement of teat number (Hirooka et al. 2001). In contrast, although teat number is easily measured in both males and females, it is not a likely candidate for MAS because first, there are a lot of QTL detected for teat number on other chromosomes also and secondly there are other more important traits affecting litter size in swine. Moreover, pleiotrophic effects on several reproductive traits such as ovulation rate in Meishan pigs have been reported (Rohrer 2000). Wilkie et al. (1999) observed two suggestive QTL for uterine length and ovulation rate on porcine chromosome 7 . Because these two parameters affect litter size to a considerable degree, Leymaster \& Johnson (1994) concluded that selection for ovulation rate and uterine capacity might produce the greatest response in litter size. However, these parameters are difficult to measure, especially in the same animals in which both traits are only measurable for one parity. Until now, only
Rohrer et al. (1999), Wilkie et al. (1999) and Isler et al. (2002) investigated both traits in the same animals. When ovulation rate and uterine capacity have an effect on litter size, it can be expected, that there would also be a QTL for traits such as TNB and NBA. For the first litter, de Koning et al. (2001) reported such a QTL on the short arm on chromosome 7 near the centromere which overlaps with the QTL for ovulation rate found by Wilkie et al. (1999). These findings indicate that there could be one or more gene having an effect on litter size in this region, because litter size is directly influenced by ovulation rate. It can be noticed that the centromere region on porcine chromosome 7 is associated with reproductive traits. Properdin $(B F)$ might be one such gene which is especially important for litter size. However, in this region, a lot of other genes belonging to the MHC class III complex can be found, and hence we are not able to say whether properdin $(B F)$ is the gene leading to different litter sizes itself or if it is only a linked marker for this trait. Furthermore, it must be taken into consideration that the investigated polymorphism is located in an intronic region and the causative mutation is not yet clear. In the future, a systematic mating test is necessary in order to obtain more balanced genotype frequencies. Considering all these facts, selection progress is mainly achieved, when firstly a beneficial polymorphism is detected for a desirable trait, and rare genotypes are detected in a commercial breed at the molecular gene level in order to increase this genotype in the population.

\section{Acknowledgements}

We thank the $\mathrm{H}$. Wilhelm Schaumann Stiftung (Hamburg, Germany) for the grant for B. Buske. We also thank B. Striedinger from the commercial pig farm Polkenberg (Sachsen, Germany) and M. Buder from the PIC data service Polkenberg for the provision of the animals and data.

\section{References}

Brunsch C., Philipp U., Moser G., Leuthold G., Geldermann H., Reinecke P. (1998) Identification of QTLs with associations to heterosis in litter size in mice. XXVI International Conference on Animal Genetics, Aug., 9-14, 1998, Auckland, New Zealand.

Cassady J.P., Johnson R.K., Pomp D., Rohrer G.A., van Vleck L.D., Spiegel E.K., Gilson K.M. (2001) Identification of quantitative trait loci affecting reproduction in pigs. J. Anim. Sci., 79, 623-633. 
Hasty L.A., Brockman W.W., Lambris J.D., Lyttle C.R. (1993) Hormonal regulation of complement factor B in human endometrium. Am. J. Reprod. Immunol., 30, 63-67.

Hirooka H., de Koning D.J., Harlizius B., van Arendonk J.A.M., Rattink A.P., Groenen M.A.M., Brascamp E.W., Bovenhuis H. (2001) A whole genome scan for quantitative trait loci affecting teat number in pigs. J. Anim. Sci., 79, 2320-2326.

Isler B.J., Irvin K.M., Neal S.M., Moeller S.J., Davis M.E. (2002) Examination of the relationship between the estrogen receptor gene and reproductive traits in swine. J. Anim. Sci., 80, 2334-2339.

Jiang Z.H., Gibson J.P. (1998) Rapid communication: a PCR-RFLP marker at the porcine complement factor B gene locus shows between-population frequency variation. J. Anim. Sci., 76, 1716-1717.

de Koning D.J., Rattink A.P., Harlizius B., Groenen M.A.M., Brascamp E.W., van Arendonk J.A.M. (2001) Detection and characterization of quantitative trait loci for growth and reproduction traits in pigs. Livestock Prod. Sci., 72, 185-198.

Leymaster K.A., Johnson R.K. (1994) Second thoughts on selection for components of reproduction in swine. In: Proc., 5th World Congr. Genet. Livest. Prod., 17, 307, Aug., 7-12, 1994. Guelph (Ontario), Canada.

Matoušek V., Kernerová N., Kolaříková O., Křížová I.I., Urban T., Vrtková I. (2003) Effect of RYRI and ESR genotypes on the fertility of sows of Large White breed in elite herds. Czech. J. Anim. Sci., 48, 129-133.

Matsumoto M., Fukuda W., Circolo A., Goellner J., Strauss-Schoenberger J., Wang X., Fujita S., Hidvegi T., Chaplin D.D., Colten H.R. (1997) Abrogation of the alternative complement pathway by targeted deletion of murine factor B. Immunology, 94, 8720-8725.

Peelman L.J., Chardon P., Vaiman M., Mattheeuws M., Van Zeveren A., Van de Weghe A., Bouquet Y., Campbell R.D. (1996) A detailed cytogenetic map of the porcine major histocompatibility complex (MHC) class III region: comparison with human and mouse MHC class III regions. Mamm. Genome, 7, 363-367.
Pinton P., Schibler L., Cribiu E., Gellin J., Yerle M. (2000) Localization of 113 anchor loci in pigs: improvement of the comparative map for humans, pigs, and goats. Mamm. Genome, 11, 306-315.

Ponsuksili S., Wimmers K., Yerle M., Schellander K. (2001) Mapping of 93 porcine ESTs preferentially expressed in liver. Mamm. Genome, 12, 869-872.

Rohrer G.A. (2000) Identification of quantitative trait loci affecting birth characters and accumulation of backfat and weight in a Meishan-White composite resource population. J. Anim. Sci., 78, 2547-2553.

Rohrer G.A., Ford J.J., Wise T.H., Vallet J.L., Christenson R.K. (1999) Identification of quantitative trait loci affecting female reproductive traits in a multigeneration Meishan-White composite swine population. J. Anim. Sci., 77, 1385-1391.

Rothschild M.F., Messer L., Day A., Wales R., Short T., Southwood O., Plastow G. (2000) Investigation of the retinol-binding protein 4 (RBP4) gene as a candidate gene for increased litter size in pigs. Mamm. Genome, 11, 75-77.

Vincent A.L., Evans G., Short T.H., Southwood O.I., Plastow G.S., Tuggle C.K., Rothschild M.F. (1998) The prolactin receptor gene is associated with increased litter size in pigs. In: Proc., 6th World Congr. Genet. Appl. Livest. Prod., 27:15-18, Jan., 11-16, 1998. Armidale, Australia.

Wada Y., Akita T., Awata T., Furukawa T., Sugai N., Inage Y., Ishii K., Ito Y., Kobayashi E., Kusumoto H., Matsumoto T., Mikawa S., Miyake M., Murase A., Shimanuki S., Sugiyama T., Uchida Y., Yanai S., Yasue H. (2000) Quantitative trait loci (QTL) analysis in a Meishan $\times$ Göttingen cross population. Animal Genetics, 31, 376-384.

Wilkie P.J., Paszek A.A., Beattie C.W., Alexander L.J., Wheeler M.B., Schook L.B. (1999) A genomic scan of porcine reproductive traits reveals possible quantitative trait loci (QTLs) for number of corpora lutea. Mamm. Genome, 10, 573-578. 